Research Article

\title{
Pharmacognostical Studies on Leaves of Madhuca longifolia (koen) Macbr.
}

Sumaira Nasreen Mohammed Tahir*, Abuzar Husain Mohammad Jaleel, Ansari Daniyal Aaquieb Ateeque Ahmed Assistant Professor, Royal College of Pharmaceutical Education and Research Centre, Malegaon, (Nashik) Maharashtra, India. B. Pharm, Royal College of Pharmaceutical Education and Research Centre, Malegaon, (Nashik) Maharashtra, India. B. Pharm, Royal College of Pharmaceutical Education and Research Centre, Malegaon, (Nashik) Maharashtra, India. *Corresponding author's E-mail: Sumairataj205@Gmail.Com

Received: 16-07-2021; Revised: 18-10-2021; Accepted: 24-10-2021; Published on: 15-11-2021.

\section{ABSTRACT}

Madhuca longifolia (koen) macbr is an ever-green tree belonging to family sapotaceae commonly known as mahua. The leaf is used by the indigenous people of Australia in curing bleeding, gums, expectorant, cushing 's disease, wound healing activity and various ailments. The present study comprises macroscopy, microscopy, histochemistry, physicochemical parameters, phytochemical studies and florescence analysis. Pharmacognosy is the initial step for determining the status of organ of plant considered as a crude medicine; hence the current study was done, TLC of flavonoid as a chemical constituents present in the drug for establishing the biomarker compound. These studies will help in future for establishing the pharmacopoeial drug standards.

Keywords: Madhuca longifolia (koen)macbr, sapotaceae, pharmacognosy, leaf.

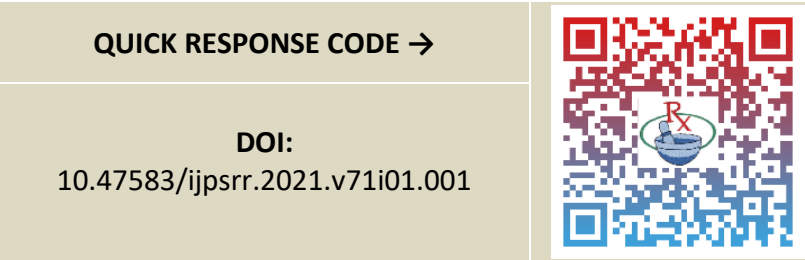

DOI link: http://dx.doi.org/10.47583/ijpsrr.2021.v71i01.001

\section{INTRODUCTION}

M adhuca longifolia (koen) macbr commonly known as Mahua belonging to family sapotaceae. ${ }^{1}$

The tree is well economic value in Maharashtra among aboriginals (Mahadeo-koli, warli tribes and agaree tribes). The leaf is recommended for wound heal, antiestrogen, leprosy, tonsillitis, skin diseases, scabies and chronic bronchitis. Although this part of plant use little application on its pharmacognostical study and present investigation was going on. ${ }^{2-6}$

The Madhuca longifolia (koen)macbr is considered as an universal cathalicon in the ayurvedic medicines. ${ }^{7-8}$

It is a large evergreen tree up to $17 \mathrm{~m}$ in height possesses long lasting foliage with milky latex .leaves are broad clustered at the ends of branches elliptic to obovate, stipulate tomentose glabrous deeply pink colour, rounded base. Flowers present near the ends of the branches. Calyx corolla, androecium and gynoecium are present 4 sepals arranged in two whorls. Cream colored corolla is present. 2024 number of stamens are present and staminoids are absent. ${ }^{9-15}$

\section{MATERIALS AND METHODS}

The leaves of Madhuca longifolia (koen)macbr were collected from local areas of Zaidpur (Barabanki) Uttar Pradesh. The plant sample was authenticated for its botanical identification and authenticated by Dr. Shashiknt Bharatrao Shisode Associate Professor. A voucher specimen has been deposited in L.V.H College Post graduate department of botany in Nashik. Voucher specimen number (L.V.H /Botany /779). After collection some of the leaf pieces were preserved in FAA solution. Remaining leaf were dried and convert into powder. Pharmacognosy of the leaf carried out by following the standard methodology. ${ }^{16-18}$

\section{Macroscopy}

The leaves were studied for its morphological characters by using the appropriate techniques and methods. ${ }^{19-21}$

\section{Microscopy}

The transverse section of leaf was taken and observed under microscope /electron microscope under the high and low power of magnification of microscope .Show in the figure no. $1,2,3,4,5,6,7,8$.
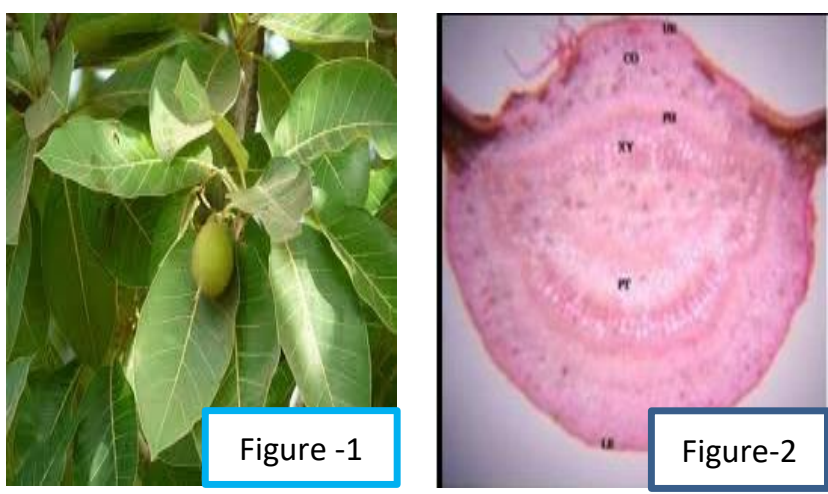

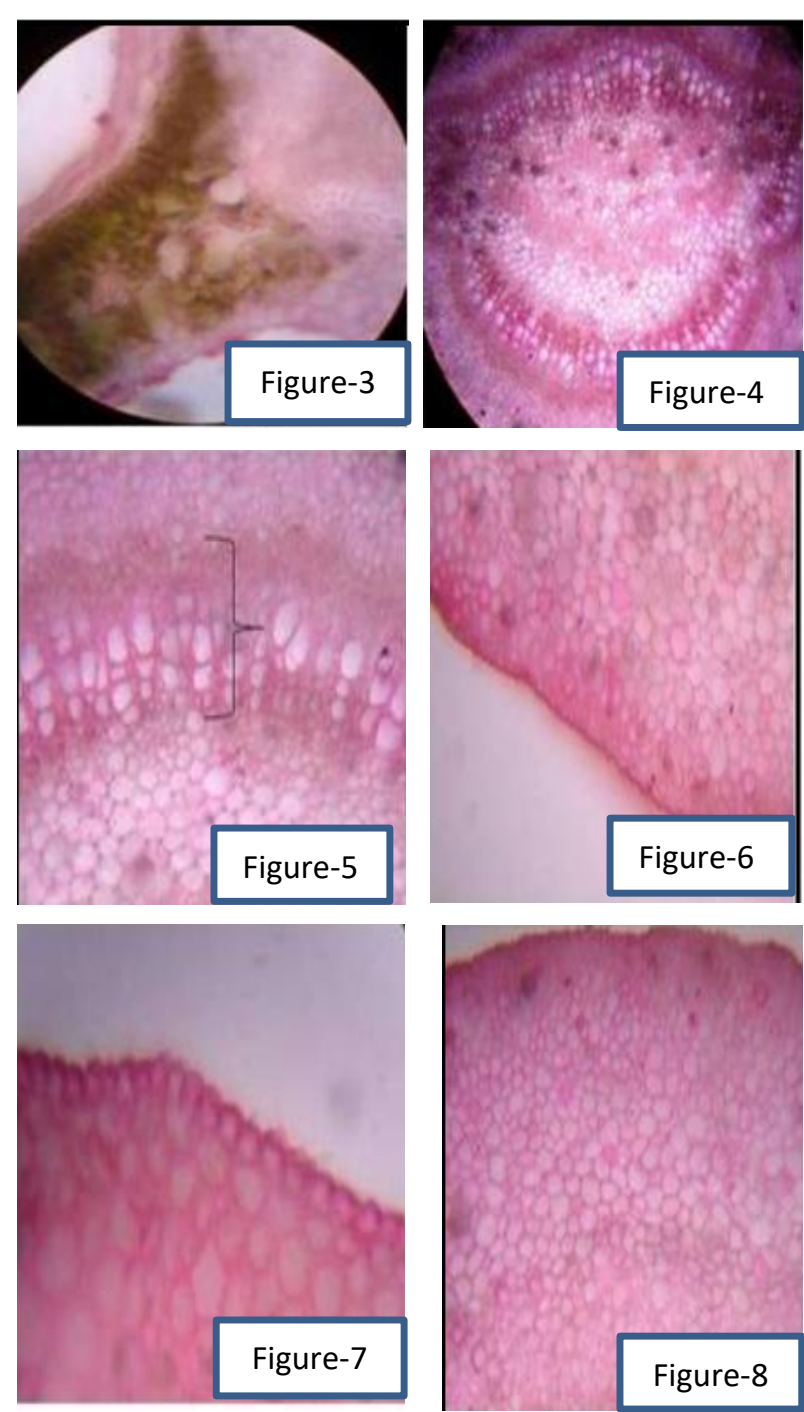

Pharmacognostical studies on leaves of maduca longifolia (koen)macbr.figure-1 - whole plant, figure 2- T.S of leaf showing epidermis, figure 3- mahuwa fruit T.S, figure 4- T.S of leaf -showing different cells, figure 5- shows the dorsiventeral lamina, figure 6- shows the shape of vascular bundles, figure 7- shows the xylem and phloem, figure 8upper epidermis.

\section{Histochemistry}

The microscopical studies for transverse section of leaf contains cells contents were performed using standard methods.

\section{Powder study}

The powdered drug was moistened by soaking on it chloralhydrate solution and for microscopical studies it is soaked in $50 \%$ glycerine.

\section{Proximate analysis}

The physiocochemical parameters like -ash values and extractive values where done.

\section{Fluorescence analysis}

The fluorescence study was carried out by using a ultraviolet radiations the powdered drug is exposed to UV radiations (visible light, $254 \mathrm{~nm}, 365 \mathrm{~nm}$ ) was studied using the standard procedure.

\section{Preliminary phytochemical screening}

A known quantity of dried leaf powder was defatted first with petroleum ether and after that extracted with different solvents like organic solvents and water it gives different concentrations of yield. These extract were tested for different constituents.

\section{Thin Layer Chromatography}

Extraction of Flavonoids : Powdered sample (5g) was defatted first after that extracted with methanol in soxhlet apparatus for two hours and solvent was evaporated the residue was collected and stored in well closed container.

For TLC dried residue was dissolved in methanol and the standard flavonoid (quercetin $98 \% \mathrm{w} / \mathrm{w}$ ) also dissolved in methanol $(2 \mathrm{mg} / \mathrm{ml})$. Both the samples were loaded on silica gel $60 \mathrm{~F}$ (E Merck). The plate was developed using, ethyl acetate :glacial acetic acid :formic acid :water (5: 0.5: 0.5 :1.3). The plate was sprayed with NP/PEG.

\section{RESULT AND DISCUSSIONS}

Macroscopical characters of leaf show on table no. 1

Table 1: Macroscopical characters of leaf

\begin{tabular}{|c|c|c|}
\hline Sr no & Morphology of leaf & Observation \\
\hline 1 & Colour & Green \\
\hline 2 & Odour & Characteristic \\
\hline 3 & Taste & Bitter \\
\hline 4 & Size & $\begin{array}{c}11-15 \mathrm{~cm} \text { long } \\
5-8 \mathrm{~cm} \text { wide }\end{array}$ \\
\hline 5 & Shape & Lanceolate to ovate \\
\hline 6 & Texture & Short \\
\hline 7 & Apex & Acute \\
\hline 8 & Arrangements & Apposite \\
\hline 9 & Appearance & Smooth \\
\hline 10 & Petiole & short \\
\hline
\end{tabular}

\section{Microscopical characters}

Transverse section of leaves exhibit following: ${ }^{22-23}$

Cork : Two types of cork cell are present thin walled and thick walled these are radially flattened cells filled with tannins and starch grains are scattered in various layers are observed.

Upper epidermis : present below the cuticle of the leaf single layered cells found.

Palisade layer: xylem, phloem,

Xylem: specialized tissues are present at internal hydrophobic surface.

Phloem : polygonal compactly arranged cortical cells.

Trichomes :covering and uniseriate type of trichomes. 
Stomata :both upper and lower surface contains paracytic stomata.

Powder study : powdered leaf is green in color, bitter and short in in texture. Microscopically powder shows : cortical cells, cork cells, crystal fibres, calcium oxalate crystals and starch grains.

Histochemical test - The section of leaf shows the presence of different primary chemical constituents by treating with different reagents such as glucosides, starch, calcium oxalate crystals and mucilages.

Physicochemical studies - The physicochemical constants includes ash values and extractive values. Shown in the table no. 2.
Table 2: Physicochemical studies

\begin{tabular}{|c|c|c|}
\hline S.no & Parameters & Determined value \% w/w \\
\hline $\mathbf{a}$ & $\begin{array}{c}\text { Extractive values } \\
\text { Alcohol soluble } \\
\text { extractive values }\end{array}$ & \multicolumn{2}{|c|}{27.5} \\
\hline 2 & $\begin{array}{c}\text { Water soluble } \\
\text { extractive value }\end{array}$ & 26.02 \\
\hline $\mathbf{b}$ & Ash values & \\
\hline 1 & Total ash & 6 \\
\hline 2 & Water soluble ash & 0.24 \\
\hline 3 & Acid insoluble ash & 0.167 \\
\hline
\end{tabular}

\section{Fluorescence analysis}

The leaf powder treated with different reagents exhibit various colors in the UV light. The predominant colour was green in most of the test shown in table no. 3.

Table 3: Fluorescence analysis

\begin{tabular}{|c|c|c|c|c|}
\hline Sr no & Material/treatment & $\begin{array}{c}\text { Observation under UV } \\
\text { Visible light }\end{array}$ & Short UV (254nm) & Long UV (365 nm) \\
\hline 1 & Drug powder & Muddy green & green & Light brown \\
\hline 2 & Drug + coc. HCL & Brown & Black & Black \\
\hline 3 & Drug + 1 M NaoH & Light brown & Brown & Blackish brown \\
\hline 4 & Drug + ethanol & yellow & green & Light green \\
\hline 5 & Drug + acetic acid & Pale yellow & Green & Dark green \\
\hline 6 & Drug + pet ether & green & Dark green & Blackish green \\
\hline 7 & Drug + water & Green & Brown & Brown \\
\hline
\end{tabular}

\section{Preliminary phytochemical analysis}

This study reveals the presence of various type of primary and secondary metabolites shown in table no. 4 .

Table 4: Phytochemical analysis

\begin{tabular}{|c|c|c|c|c|}
\hline Sr no & Phytoconstituents & Water extract & Methanol extract & Ethanol extract \\
\hline 1 & Alkaloids & + & + & + \\
\hline 2 & Flavonoids & - & + & + \\
\hline 3 & Tannins and phenolic compounds & - & + & + \\
\hline 4 & Glycosides & + & + & + \\
\hline 5 & Steroids & - & - & - \\
\hline
\end{tabular}

\section{CONCLUSION}

The macroscopical and microscopical studies helps in the identification of crude drug. The powdered study, phytochemical analysis and fluorescence test authentication of the crude drug. The preliminary phytochemical test can provide the idea about presence of primary and secondary metabolites. TLC detected the presence of flavonoids as a biomarker compound it is the potential source of quercetin yielding herbal drug.

Acknowledgement: I am saying the special thanks to my guide $\mathrm{Dr}$. Jitendra Yadav Nehete.

\section{REFERENCES}

1. Evans WC , A Book of Pharmacognosy. Sunders Publications, 2009; $16^{\text {th }}$ edition; 2009: 03-04.

2. Mishra S and Padhan S, Madhuca longifolia (sapotaceae): A Review of its Traditional Uses and Nutritional Properties, International Journal of Humanities and Social Science Inventions, 2013; 2(5): 2319-7714.

3. Meena J, Meena D, Medicinal and Commercial Potential of Madhuca Indica: A Review, International Journal of Medical and Health Research, 2016; 2(12): 23-26. 
4. Akshatha K.N, Murthy M And Lakshmidevi N, Ethnomedical Uses Of Madhuca Longifolia -A Review, International Journal Of Life Sciences And Pharma Research, 2013; 3(1):51-58.

5. Kamal A, Quantitative Phytochemical Analysis of Madhuca longifolia, Indian Journal of Plant Sciences, 2014; 3(4): 38-41.

6. Annalakshmi R, Uma R, Chandran G, Sahayam C.S, Charles A, Evaluation of Physicochemical Constants and Phytochemical Analysis of Madhuca longifolia, International Journal of Natural Products Research, 2012;18:32-39.

7. Sinha J, Vinit S, Jyotsana S and Rai A.K, Phytochemistry Ethnomedical Uses and Future Prospects of Mahua (Madhuca longifolia)as a Food : A Review, Journal of Nutrition and Food Sciences 2017:41:2155-9600.

8. Liang Y.Z, Xiepeishan C.K, Kelvin Chan, Quality Control of Herbal Medicine, Journal of Chromatography B, 2004; 8(1): 253-70.

9. Yadav P, Deepak S, Malik A.M and Nayak S, Madhuca longifolia (Sapotaceae): A Review of its Traditional Uses, Phytochemistry and Pharmacology, International Journal of Biomedical Research. 2012; 3(7): 291-305.

10. Kumar A, A Review on Madhuca longifolia, Research in Pharmacy and Health Sciences, 2016; 2(3): 187-95.

11. Sunita M, Sarojini M, Madhuca longifolia (Sapotaceae ), a Review of its traditional use and Nutritional Properties, International Journal of Humanities and Social Service Invention2013; 2(5): 30-36.

12. Evans W. C, Trease And Evans Pharmacognosy, 16 th $^{\text {th }}$ Edition ,Harcourt Brace And Co. Asia Pvt Lmtd., 1996.

13. Khandelwal K.R, Practical Pharmacognosy, Nirali Prakashan, 2008; $19^{\text {th }}$ edition.

14. Mahajan R.V, Amarshettiwar S.B, Gajbe N.D, Wagh S.P and Tayade R.V,Madhuka: promising millennium plant,
International Journal of Chemical Studies, 2021; 9(1): 32243229.

15. Mishra Sunita M.S and Padhan Sarojini P.S, Madhuca longifolia (Sapotaceae): A Review of its traditional use and Nutritional properties. International Journal of Humanities and Social Science Invention. 2013; 2(5): 30-36.

16. Banerji R, Mitra R. Mahua (Madhuca species): uses and potential in India. Appl. Bot. Abstract. 1996; 16: 260-261.

17. Patel M, Naik S.N. Flowers of Madhuca indical: Present Status and Future Perspectives. Indian journal of Natural Products and Resources. 2010; 1: 438- 443.

18. Sardana S, Sharma O.P. Fundamentals of Pharmacognosy, Birla Publication, Delhi, Edition. 2009; 10: 40-42.

19. Sharma S.S, Mukesh C, Kohli D.V. Wound healing activity and formulation of ether-benzene $-95 \%$ ethanol extract of herbal drug Madhuca longifolia leaves in albino rats. Journal of optoelectronics and Biomedical materials. 2010; 19(1): 13-15.

20. Sengar N.P.S, Ritesh A, A Text Book of Pharmacognosy, Pharmamed press, Hyderabad, Edition. 2009; 1: 44-45.

21. Variers P.S. Vaidyarathanam A, Indian Medicinal Plants, Orient Longman Publication, New Delhi, Edition. 1995; 1(3): 362-366.

22. Patel P.K, Janghel V, Chandel S.S, Sahu J, International journal of pharmaceutical and pharmacological research.2019; 9(3): 16-28.

23. Pandey M, Debnath M, Gupta S and Chikara S.K , Phytomedicine An ancient approach turning into future potential source of therapeutics. Journal of Pharmacognosy and Phytotherapy; 2011; 3(1): 113-117.

24. Saluja M.S, Sangameswaran B, Hura I.S, Sharma A, Gupta S.K and Chaturvedi $M$. International Journal of Drug Discovery and Herbal Research; 2011; 1(2): 55-57.

Source of Support: The author(s) received no financial support for the research, authorship, and/or publication of this article.

Conflict of Interest: The author(s) declared no potential conflicts of interest with respect to the research, authorship, and/or publication of this article.

For any question relates to this article, please reach us at: editor@globalresearchonline.net New manuscripts for publication can be submitted at: submit@globalresearchonline.net and submit_ijpsrr@rediffmail.com 